\title{
EXPLORING SERVICE QUALITY IMPACTS ON CUSTOMER SATISFACTION IN MILITARY MEDICAL CENTRES: MODERATING ROLE OF PERCEIVED VALUE
}

\author{
Azman Ismail ${ }^{1}$, Mohd Helmi Ali ${ }^{1}$, Nur Ilyani Ranlan Rose ${ }^{1}$, Anis Anisah Abdulla ${ }^{2}$, Herwina \\ $\operatorname{Rosnan}^{3}$
}

${ }^{1}$ Faculty of Economics \& Management, Universiti Kebangsaan Malaysia, Selangor, Malaysia ${ }^{2}$ Institute Islam Hadhari, Universiti Kebangsaan Malaysia, Selangor, Malaysia

${ }^{3}$ Faculty of Business Management, Universiti Teknologi Shah Alam, Selangor, Malaysia

\begin{tabular}{l} 
Info Article \\
\hline History Article: \\
Received Juni 2016 \\
Approved July 2016 \\
Published September 2016 \\
\hline Keywords: \\
Customers' perceived value; \\
Customer satisfaction; \\
Service quality; \\
SmartPLS
\end{tabular}

\begin{abstract}
Much has been written about service quality impacts on customer satisfaction. However, little research on this perspective has been carried out in military settings. The aim of this study is to examine the relationship between service quality and customer satisfaction, and moderating effects of perceived value in military medical centre. A survey method was employed and data was collected from customers at medical centers under the administration of Malaysian army organization. Analysis was performed using SmartPLS path model analysis. The results show two important findings: first, the interaction between four service quality components (i.e., tangible, reliability, responsiveness and assurance) and customers' perceived value were significantly correlated with customer satisfaction. Second, the interaction between one service quality component (i.e., tangible) were not significantly correlated with customer satisfaction. Further, this study offers discussion, implications and conclusion.
\end{abstract}

\section{MENGEKSPLOR PENGARUH KUALITAS JASA PADA KEPUASAN KONSUMEN PUSAT MEDIS MILITER: DENGAN PERAN MODERASI PERCEIVED VALUE}

\begin{abstract}
Abstrak
Banyak yang telah ditulis tentang factor yang mempengaruhi kepuasan pelanggan.Namun, sedikit penelitian tentang kepuasan pelanggan telah dilakukan dalam konteks militer. Tujuan penilitian ini adalah untuk menguji hubungan antara kualitas layanan dan kepuasan pelanggan, dan effek moderat nilai perspesi. Metode yang digunakana dalah survey dan data dikumpulkan dari pelanggan di pusat-pusatmedis di bawah organisasi administrasi tentara Malaysia. Analisis dilaksanakan menggunakan analisis model SmartPLS. Hasil analisis menunjukkan dua temuan penting: pertama, interaksi antara empat komponen kualitas pelayanan (yaitu, nyata, reliabilitas, responsive danjaminan) dan nilai persespsi secara signifikan berkorelasi dengan kepuasan pelanggan. Kedua, hubungan antara satu komponen kualitas pelayanan (yaitu, nyata) tidak berkorelasi dengan kepuasan pelanggan. Selanjutnya, penelitian ini memberikan sarana diskusi, implikasi dan kesimpulan.
\end{abstract}

JEL Classification: M3, M31

$\triangle$ Correspondence Address 


\section{INTRODUCTION}

Ghobadian et al. (1994) has identified the military as one of the important organization in service sector. Study of service quality research in military organization was conducted by Tucker and Adam (2001) investigating significance differences between military and non-military patients' satisfaction. Their findings show that these two groups shared a similar view on the satisfaction and quality. However, from the lens of social identity theory, experience in the military can alter attitude which at the same time how they perceived a certain value. The contrast between these two arguments further provides ambiguous concepts of service quality.

Investigation about workplace quality reveals that effect of service quality on customer satisfaction is not consistent if customers' perceived value are present in this relationship (Azman et al., 2009; Chang \& Wang, 2011). Many scholars state that perceived value is not an objective terminology, which has variously been described as 'complex' (Lapierre, 2000), 'multifaceted' (Babin et al., 1994), 'dynamic' (Woodruff \& Gardial, 1996; Parasuraman \& Grewal, 2000), and 'subjective' (Zeithaml, 1988).

In a customer's mind, perceived value is usually related to a customer's preferential (Zeithaml, 1988; Holbrook 1994, 1999), perceptual (Day \& Crask 2000), and cognitive-affective (Babin et al., 1994; Park 2004) is not in reference list). This concept will manifest when customers interact with a particular product or service (Sánchez-Fernández \& Iniesta-Bonillo, 2007), and evaluate product attributes, attribute performances, and consequences whether they may achieve or not their goals and purposes in use situations (Woodruff \& Gardial, 1996; Woodruff, 1997).

Furthermore, within an organizational service quality model, many scholars think that service quality, perceived value and customer satisfaction are distinct, but strongly interrelated concepts. For example, the ability of a service provider to appropriately implement tan- gible, reliability, responsiveness, assurance and empathy in performing daily job may strongly invoke customer satisfaction when customers feel that services that they receive have high value (Caruana et al., 2000; Chang, 2008; Chang $\&$ Wang, 2011).

Although the nature of this relationship has extensively been studied, the moderating effect of customers' perceived value is given less attention in the recent service quality research literature. Many researchers argue that this situation is due to the previous studies have much emphasized on conceptual definitions, disconfirmation paradigms and components of service quality in manufacturing and service organizations (Bitner, 1990; Caruanaet al., 2000).

In the context of current research, a unique perceived value of personnel with military experience may provide a different view on the service quality and customer satisfaction. Second, many service quality studies have utilized a gap analysis, simple survey and correlation analysis methods to assess customer attitudes toward overall service quality and/or particular products sold by organizations, as well as measure the strength of association between different service quality components and specific customer outcomes in service organizations (Azman et al., 2009; Kuo et al., 2009).

The literature of service quality predominantly focusses upon the non-military samples. Despite the abundance of research on service quality relation with customer satisfaction, the completeness of this relationship can be argued of its completeness without empirical evidence from military context (Azman et al., 2014). Third, previous studies have extensively elaborated the perceived value construct based on rational and emotional models, but the inconsistent result of customers' perceived value as an important moderating variable is not thoroughly discussed in the service quality research literature (Eggert \& Ulaga, 2002; Chang \& Wang, 2011).

Consequently, previous studies have provided general findings and this finding is not adequate to be used as useful guidelines by 
Azman Ismail, dkk / Exploring Service Quality Impacts On Customer Satisfaction In Military ...

practitioners in understanding the complexity of service quality construct and formulating action plans to achieve ultimate goals of service quality program in knowledge based organizations (Eggert \& Ulaga 2002; Azman et al., 2009; Chang \& Wang 2011). Thus, it motivates the researchers to fill in the gap of literature by quantifying the moderating effect of customers' perceived value in relationship between service quality and customer satisfaction.

In a nutshell, this study aims to provide an empirical evidence of relationship between service quality and customer satisfaction from using sample of patients who are receiving treatment in military medical centre. In addition, based on the argument of identity theory the study has included perceived value as the moderating variable in the investigation. The article is organized as follows.

After this section, a literature review on three important components comprising service quality, customer satisfaction, and perceived value is provided. Following the review, a conceptual model and hypotheses were developed and presented. The methodology section explains the research process used in the present study. Section of results and discussion presents the implication of the research results. Towards the end of this article, a summary of the findings, implication, and limitation is provided.

\section{Hypothesis Development}

Quality is a multi-dimensional construct and maybe interpreted based on global economy changes. In a manufacturing, construction and/ or mining based economy, quality construct is defined as value (Feigenbaum, 1951), conformance to requirements (Crosby, 1979), and fitness for use (Juran et al., 1974), products and services that fulfill or beyond customers' expectations (Kano, 1884), and a predictability degree of uniformity and dependability at low cost and appropriate to the market (Deming, 1986).

This quality perspective uses an objective quality (i.e., good quality) to evaluate a thing or an event that are clearly measurable and verifiable (Zeithaml, 1988; Ladhari, 2009). When the world economy has changed its paradigm to knowledge based economy, many employers rapidly develop and transform service sector using an advanced integrated communication technology.

This development has changed the paradigm of assessing quality from using an objective quality to customer based service quality (Parasuraman, et al., 1985; Juwaheer, 2004). Under this new perspective Parasuraman et al. (1985, 1988, 1991 \& 1994) suggest that service quality should be conceptualized and/or assessed based on customer's perspective because it consists of four unique features: intangibility, heterogeneity, perishability, and inseparability (Ladhari, 2009). These unique features mean that service quality is a more elusive and abstract construct than objective quality (i.e., good quality) (Ladhari, 2009; Parasuraman et al., 1985, 1988).

For this purpose, Parasuramanet al. (1985, 1988 \& 1991) have conceptualized service quality as a type of attitude which involves an overall impression or global value judgment about a service (Parasuraman et al., 1988; Zeithaml, 1988; Sureshchandar, Rajendran and Anantharaman, 2002; Ladhari, 2009). This attitude shows a "gap" between what consumers expect that a service should offer and their views about the actual performance of the service (Ladhari, 2009; Parasuraman et al., 1988). For example, if customers view that services that they receive from an organization or use a particular product sold by an organization will fulfil their needs and expectations this may show that service quality is achieved (Sureshchandar et al., 2002; SánchezFernández and Iniesta-Bonillo, 2007; Brady and Cronin, 2010; Kitapci, et al, 2014).

A review of the past literature pertaining to service quality shows that there is no one best measurement approach to determine the effectiveness of service quality in various organizations. For example, Gronroos (1984) suggests that service quality includes two core components: technical quality (i.e., what customers' received from services provided by an organization) and functional quality (i.e., how an orga- 
nization delivers services to customers) (Brady \& Cronin, 2010). Conversely, Parasuraman et al. (1991, 1994) propose that service quality consists of five core components: tangible (physical facilities, equipment, and appearance of workers), reliability (ability to perform the promised service dependably and accurately), responsiveness (willingness to help customer and provide prompt service), assurance (knowledge and courtesy of workers and their abilities to inspire trust and confidence), and empathy (caring, individualized attention the organization provides its customers).

These components were originally applied in assessing the effectiveness of service quality at five service settings: retail banking, credit card services, repair and maintenance of electrical appliances, long-distance telephone services, and title brokerage. In a more recent study, the instrument has been advanced and modified by contemporary scholars and practitioners to measure service quality in a wide variety of service environments (Ladhari, 2009; Brady \& Cronin, 2010; Azman et al., 2014).

Among service quality models, Parasuramanet al.'s (1985, 1988, 1991, 1994) perspective has been given more attention by many scholars and practitioners to measure service quality in service organizations (Asubonteng et al., 1996; Saunders, 2008; Azman et al., 2014). They prefer to use this perspective because it clearly explains about the service quality construct and empirical operationalization of the scale (Arasli, et al., 2005; Badri, et al., 2005; Jabnoun \& Khalifa, 2005; Landrum et al., 2007), meets the acceptable standard of validity and reliability analyses (Parasuraman et al., 1991, 1994; Ladhari, 2009), and can be generally applied, adapted and/ or replaced to measure the performance of service quality in various service contexts (Ladhari, 2009; Işık et al., 2011; Azman et al., 2014).

Extant studies about service sector performance highlight that the capability of service providers to appropriately implement tangible, reliability, responsiveness, assurance and em- pathy in performing daily job may have a significant impact on customer outcomes, especially customer satisfaction (Rahim et al., 2010; Chang \& Wang, 2011).

According to a customer related service perspective, customer satisfaction is often interpreted based on several perspectives such as an assessment output of customers' comparison between expected performance with actual performance (Churchhill \& Surprenant 1982; Rosen \& Suprenant 1998), an emotional reaction of customers about the use of product and/or service (Woodruff et al., 1983), a difference between customers' expectations and experience performance after using the particular products or services (Kotler \& Clarke 1987; Rahim et al., 2010), a decision made by customers about the service quality, product quality and price (Zeithaml et al., 1988; Parasuraman \& Berry, 1991), and an inner view resulted from customer's own experience from the service (Liljander \& Strandvik, 1993). The discussion shows that customers will experience high satisfaction when services provided by a services provider may fulfill their needs and expectations ( $\mathrm{Su}$ reshchandar et al., 2002; Rahim et al., 2010).

The service quality literature has been used as foundation of establishing a conceptual framework for this study. Figure 1 explains two major conditions: first, relationship between service quality and customer satisfaction. Second, relationship between service quality and customer satisfaction is moderated by customers' perceived value.

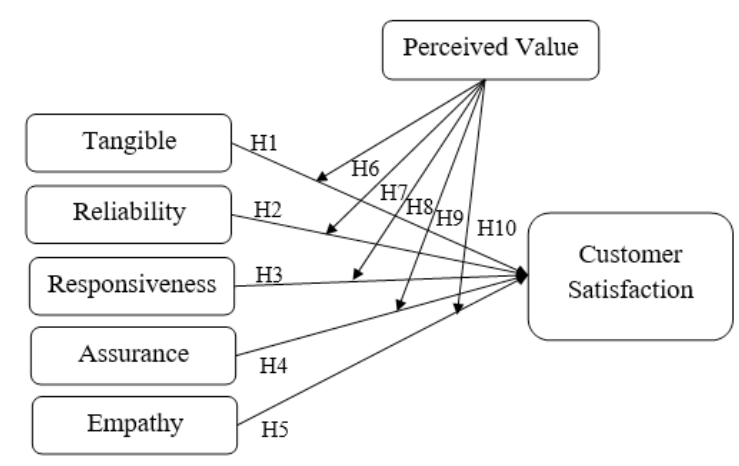

Figure 1. Proposed Model 
Azman Ismail, dkk / Exploring Service Quality Impacts On Customer Satisfaction In Military ...

Parasuraman et al., (1985, 1988, 1991, 1994) gap analysis model suggests that perceived service quality gap is viewed as the difference between expected and perceived service will strongly determine the achievement of service quality instrument (i.e., tangible, reliability, responsiveness, assurance and empathy). The notion of this theory is consistent with the considerable service quality research literature. For example, several previous studies were conducted using a direct effects model to examine service quality practices in different samples like perceptions of 145 tourists (Bitner, 1990), 80 personal interviews were conducted over a period of four weeks (Caruana et al., 2000), 102 academic staff of a Malaysian public institution of higher learning (Azman et al., 2009), college and graduate students of 15 major universities in Taiwan (Kuo et al., 2009), 147 customers of Sepah Bank branch around Fatemi St., Tehran, Iran (Rahim et al., 2010), 43.7 percent of respondents shopped once or twice and 33.9 per cent of respondents shopped 3-5 times in Taiwan (Chang \& Wang, 2011).

The outcomes of these surveys found that the ability of service providers to appropriately implement tangible, responsiveness, reliability, assurance and empathy in performing daily job had been an important predictor of customer satisfaction (Bitner, 1990; Caruana et al., 2000; Azman et al., 2009; Kuo et al., 2009; Rahim et al., 2010; Chang \& Wang, 2011). Therefore, it was hypothesized that:

$\mathrm{H1}$ : There is a positive relationship between tangible and customer satisfaction

$\mathrm{H} 2$ : There is a positive relationship between reliability and customer satisfaction

H3: There is a positive relationship between responsiveness and customer satisfaction

H4: There is a positive relationship between assurance and customer satisfaction

H5: There is a positive relationship between empathy and customer satisfaction

The moderating role of perceived value is consistent with the notion of behavioral model. First, Zeithaml's (1988) means-end model ex- plains that perceived value construct incorporates unidimensional construct and multi-dimensional construct. In terms of a unidimensional construct standpoint, a consumer assesses the overall utility of a product (Zeithaml, 1988). For example, a customer perceived the value that he/ she receives in making his/her purchase (Sánchez-Fernández \& Iniesta-Bonillo, 2007).

Conversely, in a multi-dimensional standpoint, customers use a narrow approach to assess customers' perceived value using a variety of notions (such as, perceived price, value of goods and services, value of buyer-seller relationships, and customers evaluate a supplier's total offering (Mathwick et al., 2002; Khalifa, 2004; Lindgreen \& Wynstra, 2005; ).

The discussion shows that perceived value is a higher-level construct where individuals often evaluate overall utility of products (uni-dimensional construct or single overall construct) or utility of particular products (multi-dimensional construct or multi-facet construct) based on their perceptions of price, quality, and value, rather than objective attributes (e.g., actual prices or actual quality). If individuals put a greater value about the objective product attributes this may invoke their perceived value about the products and this situation may lead to greater consumption behavior (Lindgreen \& Wynstra, 2005; Sánchez-Fernández \& Iniesta-Bonillo, 2007; Permana, 2013).

Tellis and Gaeth's (1990) theory of utility suggests that perceived value derived from the difference between the 'utility' provided by the attributes of a product and the 'disutility' represented by the price paid. If customers experience high of low value about the utility or consumption of products (e.g., monetary value of a product, time, effort and search involved in the overall cost or sacrifice) may strongly affect their attitudes and behavior (Woodruff \& Gardial, 1996; Afuah, 2002; Murwatiningsih, 2015).

Finally, Bagozzi's (1992) self-regulation processes proposes that customers' perceived value is a result of their appraisals about service quality and/ or products. When customers experience high in perceived value this feeling 
may induce positive their customer behavior (e.g., coping responses). Application of these theories in workplace quality shows that perceived value affects the strength of relationship between service quality and customer outcomes. The moderating effect of customers' perceived value has also gained strong support from the service quality research literature.

Further, several studies were conducted using an indirect effects model to investigate service quality practices in different service organizations, i.e., US organizations (Eggert \& Ulaga, 2002), Malaysian public institution of higher learning (Azman et al., 2009), Taiwan shopping mall (Chang \& Wang, 2011), highlighted that the ability of service providers to appropriately implement tangible, reliability, responsiveness, assurance and empathy in performing daily job could strongly invoke customer satisfaction if customers recognized that services that they received were high value. This relationship confirmed that perceived high value about the service quality offered by the organizations had led to an enhanced customer satisfaction (Caruana et al., 2000; Azman et al., 2009; Chang \& Wang 2011; Tanisah, 2015). Thus, it was hypothesized that:

H6: Customers' perceived value positively moderate the relationship between tangible and customer satisfaction

H7: Customers' perceived value positively moderate the relationship between reliability and customer satisfaction

H8: Customers' perceived value positively moderate the relationship between responsiveness and customer satisfaction

H9: Customers' perceived value positively moderate the relationship between assurance and customer satisfaction

H10:Customers' perceived value positively moderate the relationship between empathy and customer satisfaction

\section{METHOD}

A quantitative research design is adopted in this research. We use translated, i.e., English to Malay questionnaire instrument in this rese- arch. A back translation technique was used to translate the content of questionnaires in Malay and English languages in order to increase the validity and reliability of the research findings (Hulland, 1999 \& Sekaran, 2010). The survey questionnaire consists of two sections: first, service quality components, i.e., tangible had 4 items, reliability had 6 items, responsiveness had 7 items, assurance had 7 items and empathy had 4 items adjusted from Parasuramanet al.'s (1985, 1988, 1991, 1994) SERVQUAL scale.

The dimensions used to measure tangible were medical equipment, building layout and patient facilities. The dimensions used to measure reliability were solving, good service, schedule and performance. The dimensions used to measure responsiveness were feedback, priority, take care and urgent action. The dimensions used to measure assurance were comfortable, polite, confident, no complaint and believe. The dimensions used to measure empathy were cooperation, understanding and delivery. Second, perceived value had 9 items adjusted from the service quality related perceived value literature (Caruana et al., 2000; McDougall \& Levesque, 2000; Azman et al., 2009).

The dimensions used to measure perceived value were benefit, value, convenient and interaction. Third, customer satisfaction had 4 items adjusted from the customer satisfaction literature (Bitner, 1990; Eggert \& Ulaga, 2002; Azman et al., 2009). The dimensions used to measure customer satisfaction were treatment, communication and expectation. All these items were measured using a 7-item scale ranging from "very strongly disagree" (1) to "very strongly agree” (7). Demographic variables were only used as controlling variables because this study focused on customer attitudes.

The SmartPLS was employed to analyze the survey questionnaire data because it may deliver latent variable scores, avoid small sample size problems, estimate every complex models with many latent and manifest variables, hassle stringent assumptions about the distribution of variables and error terms, and handle both reflective and formative measurement models (Hen- 
Azman Ismail, dkk / Exploring Service Quality Impacts On Customer Satisfaction In Military ...

seler et al., 2009). Data of this study were analyzed using the following steps: first, construct and item validities were determined using convergent and discriminant validity analyses.

Second, construct reliability was assessed by composite reliability analysis. Third, the structural model is assessed by examining the path coefficients using standardized betas $(\beta)$ and $t$ statistics $(t>1.96)$. Fourth, the value of $f^{2}$ was used as a measure to determine the effect size of moderating variable in the model (i.e., 0.02 (weak), 0.15 (medium) and 0.35 (large) (Hair et al., 2014).

Fifth, the value of $\mathrm{R}^{2}$ was used as an indicator of the overall predictive strength of the model (i.e., 0.19 (weak), 0.33 (moderate) and 0.67 (substantial) (Chin, 2010 \& Henseleret al., 2009). Finally, the value of $q^{2}$ was used as a criterion to assess the model's predictive relevance (i.e., 0.02 (weak), 0.15 (medium) and 0.35 (large) (Hair et al., 2014).

\section{RESULT AND DISCUSSION}

Table 1 shows that the majority respondent characteristics were males $(58.0 \%)$, aged less than 20 years old (51.0\%), non-married employees (82.2\%), army patients (97.0\%), patients who received ordinary/acute treatments (96.0\%), and patients who received one time treatment in a month $(74.0 \%)$.

Table 1: Respondent Characteristic

\begin{tabular}{ll}
\hline Respondent Characteristics & Percentage \\
\hline Gender & \\
Male & 58.0 \\
Female & 42.0 \\
\hline
\end{tabular}

\begin{tabular}{lc}
\hline Age & \\
$<20$ years & 51.0 \\
21-30 years & 37.0 \\
31-40 years & 10.0 \\
$>41$ years & 2.0 \\
\hline Marital status & \\
Single & 82.0 \\
Married & 18.0 \\
\hline Patient & \\
Army & 97.0 \\
Army family & 2.0 \\
Civilian staff & 1.0 \\
\hline Type of treatment & \\
Ordinary/ acute & 96.0 \\
Chronic & 1.0 \\
Dental & 3.0 \\
\hline Frequency of treatment in a month \\
1 time & 74.0 \\
2 to 4 times & 22.0 \\
$>5$ times & 4.0 \\
\hline
\end{tabular}

Table 2 shows the factor loadings and cross loadings for different constructs, and composite reliability for different constructs. The loadings of variables more strongly on their own constructs in the model, greater than 0.70 were considered adequate. Besides, the correlation between items and factors had higher loadings than other items in the different constructs (Fornell \& Larcker, 1981; Gefen \& Straub, 2005; Chin, 2010). This result indicates that all items have met the accepTable standard of discriminant validity. Further, the values of composite reliability for all constructs were greater than 0.8 , indicating that the measurement scale used in this study had high internal consistency (Nunally \& Benstein, 1994).

Table 3 shows the results of convergent and discriminant validity analyses. All

Table 2. Factor Loadings and Cross-Factor Loadings for Different Constructs, and Composite Reliability (CR)

\begin{tabular}{lllllllll}
\hline Construct & TANG & RELB & RESP & ASSUR & EMP & PERVAL & CUSTSAT & CR \\
\hline TANG1 & 0.863 & & & & & & & 0.925 \\
TANG2 & 0.845 & & & & & & & \\
TANG3 & 0.879 & & & & & & & \\
TANG4 & 0.891 & & & & & & & \\
\hline
\end{tabular}


Table 2. Continuou

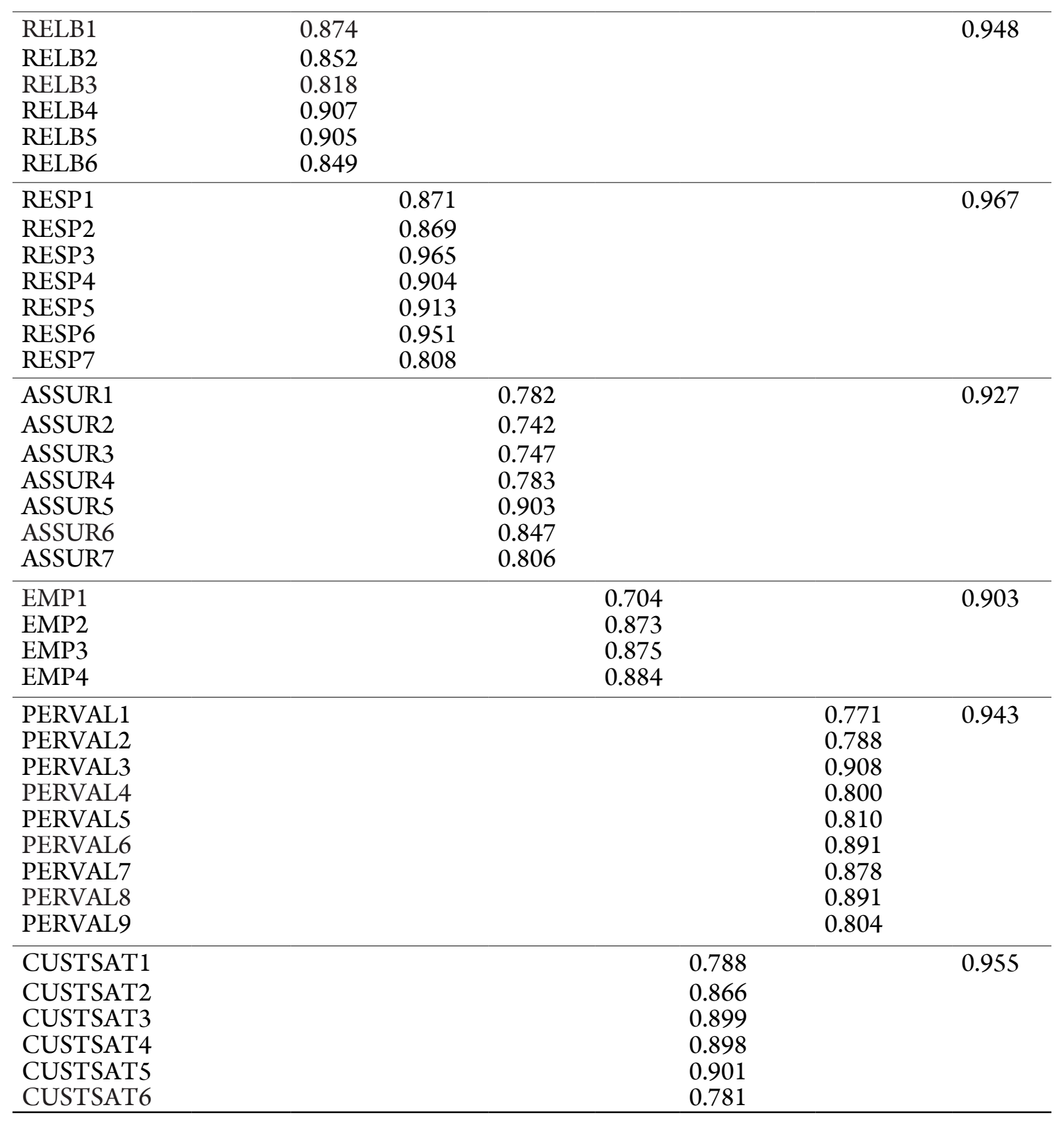

Table 3. Discriminant Validity and Convergent Validity Analyses

\begin{tabular}{lcccccccc}
\hline \multicolumn{1}{c}{ Construct } & AVE & $\mathbf{1}$ & $\mathbf{2}$ & $\mathbf{3}$ & $\mathbf{4}$ & $\mathbf{5}$ & $\mathbf{6}$ & $\mathbf{7}$ \\
\hline 1. TANG & 0.756 & $\mathbf{0 . 8 7 0}$ & & & & & & \\
2. RELB & 0.754 & 0.820 & $\mathbf{0 . 8 6 8}$ & & & & & \\
3. RESP & 0.808 & 0.702 & 0.787 & $\mathbf{0 . 8 9 9}$ & & & & \\
4. ASSUR & 0.645 & 0.598 & 0.717 & 0.713 & $\mathbf{0 . 8 0 3}$ & & & \\
5. EMP & 0.701 & 0.221 & 0.490 & 0.496 & 0.519 & $\mathbf{0 . 8 3 8}$ & & \\
6. PERVAL & 0.735 & 0.433 & 0.666 & 0.508 & 0.669 & 0.707 & $\mathbf{0 . 8 5 7}$ & \\
7. CUSTSAT & 0.704 & 0.285 & 0.567 & 0.388 & 0.577 & 0.806 & 0.817 & $\mathbf{0 . 8 3 9}$ \\
\hline
\end{tabular}


Azman Ismail, dkk / Exploring Service Quality Impacts On Customer Satisfaction In Military ...

constructs had the values of average variance extracted (AVE) larger than 0.5 indicating that they met the accepTable standard of convergent validity (Fornell \& Larcker, 1981; Barclay, et al., 1995; Henseler et al., 2009). Besides that, all constructs had the values of AVE square root in diagonal were greater than the squared correlation with other constructs in off diagonal, showing that all constructs met the accepTable standard of discriminant validity (Henseler et al., 2009).

Table 4 shows the results of variance inflation factor and descriptive statistic. The means for the variables are from 5.12 to 5.70, showing that the levels of TANG, RELB, RESP, ASSUR. EMP, PERVALUE and CUSTSAT ranging from high (4) to highest level (7). The values of variance inflation factor for the relationships: 1) between the independent variable (i.e., TANG, RELB, RESP, ASSUR. EMP) and the moderating variable (i.e., PERVALUE), and 2) between the moderating variable (i.e., PERVALUE) and the dependent variable (i.e., CUSTSAT) were less than 10.0, signifying that the data were not affected by serious collinearity problem (Hair et al., 2006). This measurement model met the validity criteria.

Figure 1 shows that the inclusion of service quality components in the analysis had contributed 77 percent in the variance of customer satisfaction. Next, the outcomes of testing the research hypothesis showed five important findings: first, TANG was not significantly correlated with CUSTSAT $(B=-0.112 ; t=0.921)$, therefore $\mathrm{H} 1$ was not supported. Second, RELB was significantly correlated with CUSTSAT
$(\mathrm{B}=0.489 ; \mathrm{t}=2.744)$, therefore $\mathrm{H} 2$ was supported. Third, RESP was significantly correlated with customers' perceived value $(B=0.431$; $t=3.497$ ), therefore $H 3$ was supported. Fourth, ASSUR was significantly correlated with CUSTSAT $(B=0.249 ; t=2.496)$, therefore $\mathrm{H} 4$ was supported.

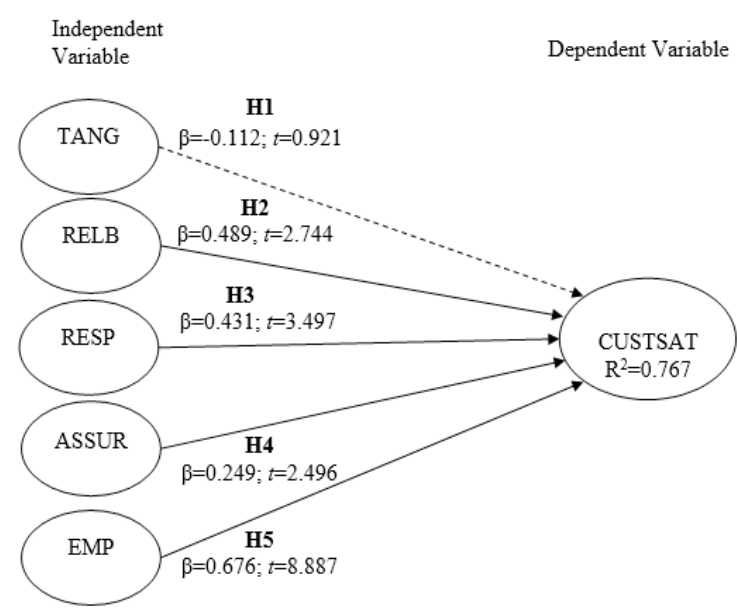

Figure 2. The result of Testing H1, H2, H3, H4 and $\mathrm{H} 5$

Note: Significant at ${ }^{*} t>1.96$

Fifth, EMP was significantly correlated with CUSTSAT $(\mathrm{B}=0.676 ; \mathrm{t}=8.887)$, therefore H5 was supported. This result demonstrates TANG does not act as an important predictor of CUSTSAT. Conversely, RELB, RESP, ASSUR and EMP do act as important predictors of CUSTSAT in the organizations.

As an extension of testing the research hypotheses, other tests were further conducted to determine the effect sizes for all constructs, overall predictive strength of the model and pre-

Table 4. Collinearity and Descriptive Statistic Statistics

\begin{tabular}{llll}
\hline \multicolumn{1}{c}{ Construct } & Mean & \multicolumn{1}{c}{ Standard Deviation } & Variance Inflation Factor \\
\hline 1. TANG & 5.55 & .611 & 3.706 \\
2. RELB & 5.49 & .643 & 5.967 \\
3. RESP & 5.70 & .658 & 3.339 \\
4. ASSUR & 5.36 & .655 & 2.283 \\
5. EMP & 5.34 & .708 & 2.382 \\
6. PERVAL & 5.24 & .673 & 3.839 \\
7. CUSTSAT & 5.12 & .748 & \\
\hline
\end{tabular}


dictive relevant for the reflective endogenous latent variable in the hypothesized model. The result of testing effect size $\left(\mathrm{f}^{2}\right)$ for the service quality showed three important findings: first, TANG had $\mathrm{f}^{2}$ value 0.014 and ASSUR had $\mathrm{f}^{2}$ value 0.107 were lower than 0.15 (Hair et al., 2014), indicating that they had small effect. Second, RELB had $\mathrm{f}^{2}$ value 0.197 and RESP had $\mathrm{f}^{2}$ value 0.250 were higher than 0.15 (Hair et al., 2014), showing that they had medium effect.

Third, EMP had $\mathrm{f}^{2}$ value 1.126 was higher than 0.35 (Hair et al., 2014), signifying that they had large effect. Besides that, the value of $\mathrm{R}^{2}$ for CUSTSAT was higher than 0.67 (Chin, 2010 \& Henseleret al., 2009), signifying that the overall predictive strength of the model was substantial. A test of predictive relevance for the reflective endogenous latent variable was further conducted based on Stone-Geisser's formulae: q2 $=$ Q2included - Q2excluded / 1 - Q2 included $=0.525$, indicating that it was greater than zero for the reflective endogenous latent variable. This result has predictive relevance. In terms of explanatory power, the $\mathrm{q}^{2}$ value for CUSTSAT was greater than 0.35 , showing that it had large predictive relevance (Hair et al., 2014).

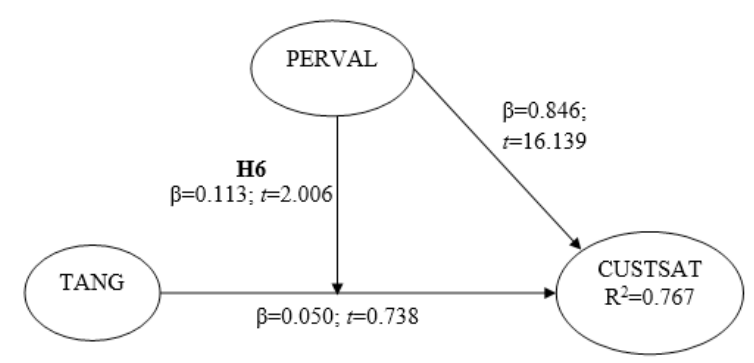

Figure 3. The Result of Testing H6

Note: Significant at ${ }^{*} t>1.96$.

Figure 3 shows that the inclusion of PERVALUE in the analysis had contributed 70 percent in the variance of customer satisfaction. Next, the outcomes of testing the research hypothesis showed that interaction between TANG and PERVALUE was significantly correlated with customer satisfaction $(\mathrm{B}=0.113$; $t=2.006)$, therefore H6 was supported. This result demonstrates that customers' perceived value act as an important moderating variable in the relationship between tangible and customer satisfaction in the organizations.

As an extension of testing the research hypotheses, other tests were further conducted to determine the effect sizes for all construct, overall predictive strength of the model and predictive relevant for the reflective endogenous latent variable in the hypothesized model. The result of testing effect size $\left(\mathrm{f}^{2}\right)$ for the interaction between TANG and PERVALUE showed that it had $\mathrm{f}^{2}$ value 0.045 lower than 0.15 (Hair et al., 2014), indicating that it had small effect. Besides that, the value of $\mathrm{R}^{2}$ for CUSTSAT was higher than 0.67 (Henseler et al., 2009; Chin, 2010), signifying that the overall predictive strength of the model was substantial.

A test of predictive relevance $\left(\mathrm{q}^{2}\right)$ for the reflective endogenous latent variable was further conducted based on Stone-Geisser's formulae: q2 = Q2included - Q2excluded / 1 - Q2 included $=0.473$, indicating that it was greater than zero for the reflective endogenous latent variable. This result has predictive relevance. In terms of explanatory power, the $\mathrm{q}^{2}$ value for CUSTSAT was greater than 0.35 , showing that it had large predictive relevance (Hair et al., 2014).

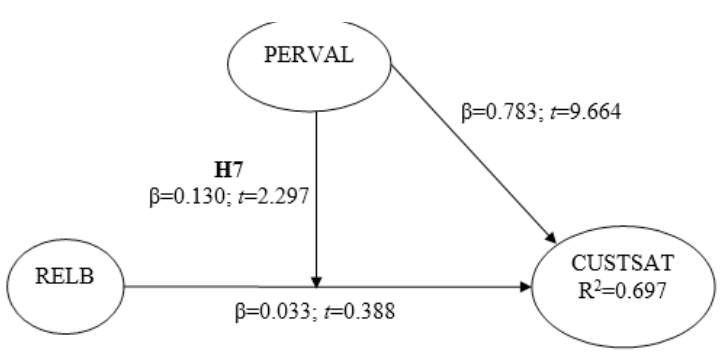

Figure 4. The Result of Testing $\mathrm{H} 7$

Note: Significant at ${ }^{*} \mathrm{t}>1.96$

Figure 4 shows that the inclusion of PERVALUE in the analysis had contributed 70 percent in the variance of customer satisfaction. Next, the outcomes of testing the research hypothesis showed that interaction between RELB and PERVALUE was significantly corre- 
Azman Ismail, dkk / Exploring Service Quality Impacts On Customer Satisfaction In Military ...

lated with customer satisfaction $(\mathrm{B}=0.130$; $\mathrm{t}=$ 2.297), therefore $\mathrm{H} 7$ was supported. This result demonstrates that customers' perceived value act as an important moderating variable in the relationship between reliability and customer satisfaction in the organizations.

The result of $\mathrm{f}^{2}$ for the interaction between RELB and PERVALUE showed that it had $\mathrm{f}^{2}$ value 0.057 was lower than 0.15 (Hair et al., 2014), indicating that it had small effect. Besides that, the value of $\mathrm{R}^{2}$ for CUSTSAT was higher than 0.67 (Henseler et al., 2009; Chin, 2010), signifying that the overall predictive strength of the model was substantial. Value of $\mathrm{q}^{2}$ is 0.470 which is greater than 0.35 , indicating that it was greater than zero for the reflective endogenous latent variable showing that it had large predictive relevance (Hair et al., 2014).

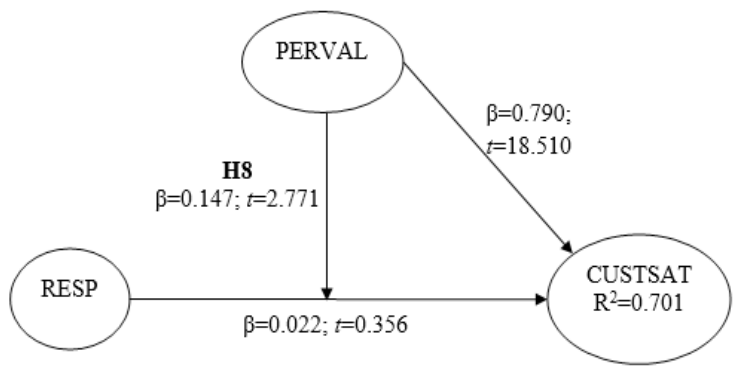

Figure 5. The Result of Testing H8

Note: Significant at ${ }^{*} \mathrm{t}>1.96$

Figure 5 depicts that the inclusion of PERVALUE in the analysis had contributed 70 percent in the variance of customer satisfaction. Next, the outcomes of testing the research hypothesis showed that interaction between RESP and PERVALUE was significantly correlated with CUSTSAT $(\mathrm{B}=0.147 ; \mathrm{t}=2.771)$, therefore $\mathrm{H} 8$ was supported.

This result demonstrates that customers' perceived value act as an important moderating variable in the relationship between responsiveness and customer satisfaction in the organizations. The $\mathrm{f}^{2}$ for the interaction between RESP and PERVALUE showed of value 0.076 which was lower than 0.15 (Hair et al., 2014), indicating that it had small effect. Besides that, the value of $\mathrm{R}^{2}$ for CUSTSAT was higher than 0.67 (Henseler et al., 2009; Chin, 2010), signifying that the overall predictive strength of the model was substantial. The value of $\mathrm{q}^{2}=0.475$, indicating that it was greater than zero for the reflective endogenous latent variable and had large predictive relevance (Hair et al., 2014).

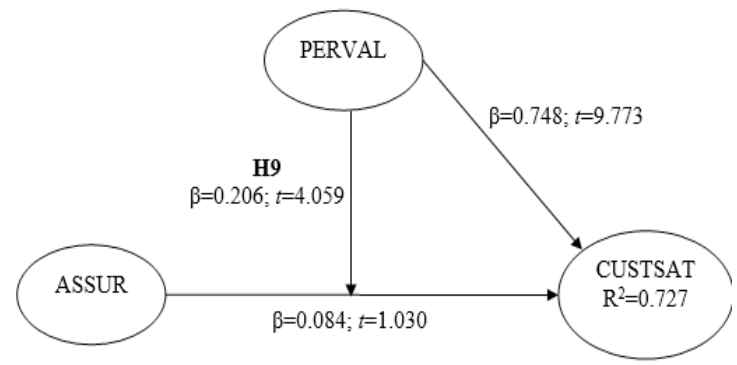

Figure 6. The Result of Testing H9

Note: Significant at ${ }^{*} \mathrm{t}>1.96$

Figure 6 shows that the inclusion of PERVALUE in the analysis had contributed 73 percent in the variance of customer satisfaction. Next, the outcomes of testing the research hypothesis showed that interaction between ASSUR and PERVALUE was significantly correlated with CUSTSAT $(B=0.206 ; \mathrm{t}=4.059)$, therefore $\mathrm{H} 9$ was supported. This result demonstrates that customers' perceived value act as an important moderating variable in the relationship between assurance and customer satisfaction in the organizations.

The result of testing effect size $\left(\mathrm{f}^{2}\right)$ for the interaction between ASSUR and PERVALUE showed that it had $\mathrm{f}^{2}$ value 0.168 was higher than 0. 15 (Hair et al., 2014), indicating that it had medium effect. Besides that, the value of $\mathrm{R}^{2}$ for CUSTSAT was higher than 0.67 (Henseler et al., 2009; Chin, 2010), signifying that the overall predictive strength of the model was substantial. A test of predictive relevance for the reflective endogenous latent variable was further conducted based on Stone-Geisser's formulae: q2 = Q2included - Q2excluded / 1 - Q2 included $=0.484$, indicating that it was greater than zero for the reflective endogenous latent variable. This result has predictive relevance. 
In terms of explanatory power, the $\mathrm{q}^{2}$ value for CUSTSAT was greater than 0.35 , showing that it had large predictive relevance (Hair et al., 2014).

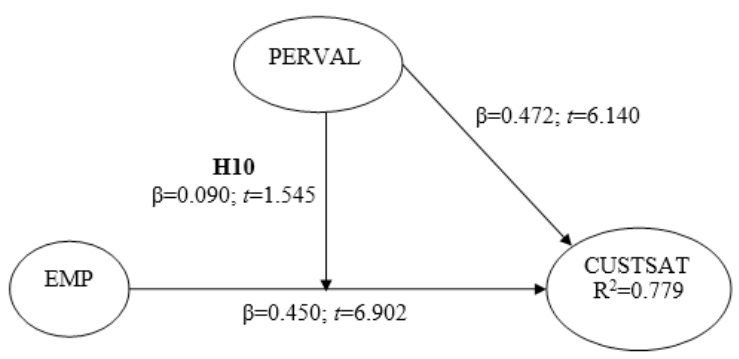

Figure 7: The Result of Testing H10

Note: Significant at ${ }^{*} t>1.96$

Figure 7 shows that the inclusion of PERVALUE in the analysis had contributed 78 percent in the variance of customer satisfaction. Next, the outcomes of testing the research hypothesis showed that interaction between EMP and PERVALUE was insignificantly correlated with CUSTSAT $(B=0.090 ; \mathrm{t}=1.545)$, therefore $\mathrm{H} 10$ was not supported. This result demonstrates that customers' perceived value does not act as an important moderating variable in the relationship between empathy and customer satisfaction in the organizations. The result of testing effect size (f2) for the interaction between EMP and PERVALUE showed that it had $\mathrm{f} 2$ value 0.025 was higher than 0.15 (Hair et al., 2014), indicating that it had medium effect.

Besides that, the value of $\mathrm{R} 2$ for CUSTSAT was higher than 0.67 (Henseler et al., 2009; Chin, 2010), signifying that the overall predictive strength of the model was substantial. A test of predictive relevance for the reflective endogenous latent variable was further conducted based on Stone-Geisser's formulae: q2 = Q2included - Q2excluded / 1 - Q2 included $=0.533$, indicating that it was greater than zero for the reflective endogenous latent variable. This result has predictive relevance. In terms of explanatory power, the $\mathrm{q} 2$ value for CUSTSAT was greater than 0.35 , showing that it had large predictive relevance (Hair et al., 2014).
The findings of this study show that perceived value does act as an important moderating variable in between four service quality components (i.e., tangible, reliability, responsiveness, and assurance) and customer satisfaction. Conversely, perceived value does not act as an important moderating variable in between one service quality component (i.e., empathy) and customer satisfaction. In the context of this study, top management have taken proactive actions to plan, maintain, and monitor their services to customers based on the broad policies and procedures as set up by their stakeholders.

The majority respondents view that the levels of tangible, reliability, responsiveness, assurance, empathy, perceived value and customer satisfaction are high. This situation explains that implementation of tangible, reliability, responsiveness, and assurance in performing daily job may strongly invoke customer satisfaction when customers recognize that services that they receive are important to achieve their goals. While, implementation of empathy in performing daily job may not strongly enhance customer satisfaction when customers feel that services that they receive are not able to achieve their goals.

This study provides three important implications: theoretical contribution, robustness of research methodology, and practical contribution. With respect to theoretical contribution, this study reveals that interaction between four service quality components (i.e., tangible, reliability, responsiveness and assurance) and perceived value has been important predictor of customer satisfaction in the organizations. This finding also has supported and extended studies by Caruana et al., 2000; Eggert \& Ulaga, 2002; Azman et al., 2009; Chang \& Wang, 2011). Conversely, interaction between service quality and perceived value has not been important predictor of customer satisfaction in the organizations.

A careful observation of the semi-structured interview results shows that this finding may affected by external factors: first, employees who work in different job levels and categories 
Azman Ismail, dkk / Exploring Service Quality Impacts On Customer Satisfaction In Military ...

have to strictly follow standardized rules and regulations in executing daily job. This condition will decrease their opportunities to use discretion and respond in solving different customers' demands and complaints. Second, employees have different interaction skills in dealing with different customer backgrounds. This situation will not lead employees to use social standards and similar code of conducts in handling diverse customers' needs and expectations. As a result, these factors may overrule the moderating effect of customers' perceived value in the relationship between empathy and customer satisfaction in the service quality models of the organizations.

In regard with the robustness of research methodology, the survey questionnaires used in this study have met the accepTable requirements of validity and reliability analyses. This situation may lead to the production of accurate and reliable findings. In terms of practical contribution, the findings of this study have provided useful recommendations to be used as guidelines by management to improve the performance of service quality in organizations. In order to support this objective, management should give more attention on the following aspects: first, employees within the firm, i.e., military medical centre should be made aware of the important elements that effecting customer satisfaction so as to enable them complying with service quality policies and procedures in performing daily job.

The awareness on the antecedents of may create a solid base for positive shared value within the organization and eventually enhancing customer satisfaction. Second, professional trainers should be hired to train management and supporting employees in mastering soft skillsand creative problem solving techniques in fulfilling diverse customer needs and expectations. For example, patients who are coming for treatment in military medical centre may be dominant to the armies which are used to military culture. However, there are also patients who are not military-trained that requires different kind of approach. The techniques may be different due to the individual background and perceive value.

Therefore in ensuring the patients are satisfied with the service offered, the correct techniques need to be applied accordingly. Third, the type, level and/or amount of reward should be upgraded to recognize employees who have high obligations to practice a high quality standard and neglect discrimination when interacting with customers who have different backgrounds. Fourth, recruitment policy should be oriented to hire and select a qualified, experienced, trained, and knowledgeable personto fulfil vital key management positions. The benefits of this decision is that the management can effectively counsel, mentor and coach junior managers and supervisors to appropriately practice service quality based on international quality management standards.

Fifth, since front line employees are the majority group, they should be appropriately trained with the standard operating procedures in receiving patients. The standard operating proceduresenable them using comforTable communication style in handling diverse customer complaints and demands. If these suggestions are given more attention this may encourage customers to appreciate and accept the organizational service quality goals and procedures.

\section{CONCLUSION AN D RECOMMENDATION}

This study tested a theoretical framework that was developed based on the organizational service quality research literature. The instrument used in this study has met the accepTable requirements of the validity and reliability analyses. The outcomes of SmartPLS path model analysis displayed two important findings: first, interaction between four service quality components (i.e., tangible, reliability, reliability and assurance) and perceived value was significantly correlated with customer satisfaction, thus H6, $\mathrm{H} 7, \mathrm{H} 8$, and $\mathrm{H} 9$ were supported.

This result demonstrates that perceived value moderated the effect of all service quali- 
ty components on customer satisfaction. This finding also has supported and extended service quality research literature mostly published in other countries. Second, interaction between one service quality component (i.e., empathy) and perceived value was insignificantly correlated with customer satisfaction, thus $\mathrm{H} 9$ was not supported. A thorough review of the semistructured interview results shows that this finding may be affected by external factors: This condition will decrease their opportunities to use discretion and respond in solving different customers' demands and complaints.

Second, employees have different interaction skills in dealing with different customer backgrounds. This situation will not lead employees to use social standards and similar code of conducts in handling diverse customers' needs and expectations. As a result, these factors may overrule the moderating effect size of customers' perceived value in the relationship between empathy and customer satisfaction in the service quality models of the organizations.

There are has several limitations of this study. First, a cross-sectional research design was employed to collect data one time within the duration of this study and this method may not be able to capture causal connections between the variables of interest. Second, the outcomes of SmartPLS path model analysis have not measured the relationship between specific indicators for the independent variable, moderating variable and dependent variable.

Third, the results of survey questionnaire describe the intensity of respondent attitudes about the application of Parasuraman et al.'s (1991, 1994) five core components of service quality in military medical centers. Finally, the sample for this study was only taken from customers through non-probability sampling techniques at one organizational sector. Thus, these limitations may lead to reduce the generalization of the results to other organizational settings.

Suggestions for future research are to consider the following aspects: a) several respondent characteristics should be further explored, where this may show meaningful perspecti- ves in clarifying how individual similarities and differences affect the implementation of service quality in organizations, b) other research designs like longitudinal studies should be employed to collect data and describe the patterns of change and the direction and magnitude of causal relationships among variables of interest, c) to fully understand the effect of service quality on customer outcomes, more diverse organizations need to be involved, d) other specific theoretical constructs of service quality such as technical and environmental qualities need to be considered because they have widely been acknowledged as an important link between service quality and many aspects of customer outcomes (Gronroos, 2007; Chang, 2008; Isik et al., 2011), e) an effort to gain higher response rate is important in order to decrease response bias and common-method variance, as well as to achieve representativeness, and f) other specific components of customers' perceived value such as perceived price, value of goods and services and value of buyer-seller relationships (Khalifa, 2004; Lindgreen \& Wynstra, 2005; Sánchez-Fernández \& Iniesta-Bonillo, 2007; Vera, 2015).

\section{REFERENCES}

Afuah, A. 2002. Mapping technological capabilities into product markets and competitive advantage: The case of cholesterol drugs. Strategic Management Journal. 23 (2): 171-179.

Arasli, H., Mehtap-Smadi, A \& Katircioglu, A. T. 2005.Customer service quality in the Greek Cypriot banking industry. Managing Service Quality. (15): 41-56.

Asubonteng P, McCleary K. J, Swan J. E. 1996. SERQUAL revisited: A critical review of service quality. Journal of Service Marketing. 10 (6): 62-82.

Azman, I., Muhammad Madi, A \& Francis, S. K. 2009. Exploring the relationships among service quality features, perceived value and customer satisfaction. Journal of Industrial Engineering and Management. 2 (1): 230-250.

Azman, I., Norazila, M., Ahmad Azan, R \& Rosnan, H. 2014. Service quality in military peacekeeping mission as a determinant of cus- 
Azman Ismail, dkk / Exploring Service Quality Impacts On Customer Satisfaction In Military ...

tomer's perceived value: Empirical evidence. Intangible Capital. 10 (3): 505-527.

Babin, B. J., Darden, W. R \& Griffin, M. 1994. Work and/or fun: Measuring hedonic and utilitarian shopping. Journal of Consumer Research. 20 (4): 644-656.

Badri, M. A., Attia, S. T \&Ustadi, A. M. 2005. Testing models of care quality for discharged patients. POMS 18th Annual Conference. Dallas, Texas, U.S.A. May 4 to May 7, 2007.

Bagozzi, R. P. 1992. The self-regulation of attitudes, intentions, and behavior. Social Psychology Quarterly. 55 (2): 178-204.

Barclay, D. W., Higgins, C. A \& Thompson, R. L. 1995. The partial least squares (PLS) approach to causal modeling: Personal computer adaptation and use an illustration. Technology Studies. 1 (2): 285-324.

Bitner, M. 1990. Evaluating service encounters: the effects of physical surroundings and employee responses. Journal of Marketing. 54: 69-82.

Brady, M. K \& Cronin, J.J. 2010. Some new thoughts on conceptualizing perceived service quality: A hierarchical approach. Journal of Marketing. 65 (3): 34-49.

Caruana, A., Money, A. H \& Berthon, P. R. 2000. Service quality and satisfaction - the moderating role of value.European Journal of Marketing.34 (11/12): 1338-1353.

Chang, J. C. 2008. Taiwanese tourists' perceptions of service quality on outbound guided package tours: A qualitative examination of the SERVQUAL dimensions. Journal of Vacation Marketing. 15 (2): 164-178.

Chang, H. H \& Wang, H. W. 2011. The moderating effect of customer perceived value on online shopping behavior. Online Information Review. 35 (3): 333-359.

Chin, W. W. 2010. Bootstrap cross-validation indices for PLS path model assessment. In $V$ Esposito Vinzi, W Chin, J Hensler \& H Wold (Peny.) Handbook PLS and Marketing. New York: Springer.

Churchhill, G. A \& Surprenant, C. 1982. An investigation into the determinants of customer satisfaction.Journal of Marketing Research. 19: 491-504.

Crosby, P. B. (Ed.). 1979. Quality is free. New York: MacGraw-Hill.

Day, E \& Crask, M. R. 2000. Value assessment: The antecedent of customer satisfaction. Journal of Consumer Satisfaction, Dissatisfaction and Complaining Behavior. 13: 52-60.

Deming, W. E. 1986. Out of Crisis. Cambridge University Press.

Eggert, A \& Ulaga, W. 2002. Customer perceived value: a substitute for satisfaction in business markets? Journal of Business \& Industrial Marketing. 17 (2/3): 107-118.

Feigenbaum, A. V. 1951. Quality control: principles, practice, and administration. New York: McGraw-Hill.

Fornell, C \& Larcker, D. F. 1981. Evaluating structural Equation models with unobservable variables and measurement error.Journal of Marketing Research. 18: 39-50.

Gefen, D \& Straub, D. 2005. A practical guide to factorial validity using PLS-Graph: Tutorial and annotated example. Communication of the Association for Information Systems. 16: 91-109.

Gronroos, C. 1984. A service quality model and its marketing implications.European Journal of Marketing. 18 (4): 36-44.

Gronroos, C. 2007. Service Management: Customer Management in Service Competition. England: John Wiley \& Sons Limited.

Hair, J. F., Black, W. C., Babin, B. J., Anderson, R. E \& Tatham, R. L. 2006.Multivariate Data Analysis. Upper Saddle River, NJ: Pearson Prentice Hall.

Hair, J. F., Hult, G. T. H., Ringle, C. M \& Sarstedt, M. 2014. A Primer on Partial Least squares Structural Equation Modeling (PLS-SEM). Lost Angeles, US: Sage.

Henseler, J., Ringle, C. M \& Sinkovics, R. R. 2009. The use of partial least squares path modeling in international marketing. Advances in International Marketing. 20: 277-320.

Holbrook, M. B. 1994. The nature of customer value: An axiology of services in the consumption experience. In R. Rust \& R. L. Oliver (Eds.) Service Quality: New Directions in Theory and Practice (pp. 21-71). Thousand Oaks, CA: Sage Publications.

Holbrook, M. B. 1999. Introduction to consumer value.In M. B. Holbrook (Ed.) Consumer Value. A Framework for Analysis and Research. London: Routledge.

Hulland, J. (1999). Use of partial least square (PLS) in strategic management research: A review of four recent studies. Strategic Management Journal. 20 (2): 195-204. 
Işık, O., Tengilimoğlu, D \& Akbolat, M. 2011. Measuring health care quality with the SERVQUAL method: A comparison in public and private hospitals. Health MED. 5 (6): 1921-1930.

Jabnoun, N \& Khalifa, A. 2005.A customized measure of service quality in the UAE. Managing Service Quality. 15 (4): 374-388.

Juran, J. M., Gryna, F. M \&Bingham, R. S. 1974. Quality control handbook. McGraw-Hill.

Juwaheer, T. D. 2004. Exploring international tourists' perceptions of hotel operations by using a modified SERVQUAL approach - a case study of Mauritius.Managing Service Quality: An International Journal. 14 (5): 350-364.

Kano. 1984. Attractive quality and must-be quality. The Journal of the Japanese Society for Quality Control. 39-48.

Khalifa, A. S. 2004. Customer value: A review of recent literature and an integrative configuration. Management Decision. 42 (5-6): 64566.

Kitapci, O., Akdogan, C \& Dortyol, I. T. 2014. The impact of service quality dimensions on patient satisfaction, repurchase intentions and word-of-mouth communication in the public healthcare industry. Procedia - Social and Behavioral Sciences. 148: 161 - 169.

Kotler, P \& Clarke, R. N. 1987.Marketing for health care organizations. Englewood Cliffs, NJ: Prentice-Hall.

Kuo, Y. F., Wu, C. M \& Deng, W. J. 2009.The relationships among service quality, perceived value, customer satisfaction, and post-purchase intention in mobile value-added services. Computers in Human Behavior. 25 (4): 887-896.

Ladhari, R. 2009. A review of twenty years of SERVQUAL research. International Journal of Quality and Service Sciences. 1 (2): 172 198.

Landrum, H., Prybutok, V. R \& Zhang, X. 2007. A comparison of Magal's service quality instrument with SERPERF. Information and Management. 44: 104-113.

Lapierre, J. 2000. Customer-perceived value in industrial contexts. The Journal of Business b Industrial Marketing. 15 (2-3): 122-140.

Liljander, V \& Strandvik, T. 1993. Estimating zones of tolerance in perceived service quality and perceived service value. International Journal of Service Industry Management.4 (2): 6-28.

Lindgreen, A \& Wynstra, F. 2005. Value in business markets: What do we know? Where are we going? Industrial Marketing Management. 34 (7): 732-748.

Mathwick, C., Malhotra, N. K \& Rigdon, E. 2002. The effect of dynamic retail experiences on experiential perceptions of value: An internet and catalog comparison. Journal of Retailing. 78 (1): 51-60.

McDougall, G. H. G \& Levesque, T. 2000. Customer satisfaction with services: Putting perceived value into the equation. The Journal of Services Marketing. 14 (5): 392-410.

Murwatiningsih. 2015. Ananlysis of Perceived Quality of Education Service. Jurnal Dinamika Manajemen. 6 (1).

Nunally, J. C \& Bernstein, I. H. 1994. Psychometric Theory. New York: McGraw-Hill.

Parasuraman, A \& Berry, L. L. 1991. Marketing for services: Competing through quality. New York: The Free Press.

Parasuraman, A \& Grewal, D. 2000. The impact of technology on the quality value-loyalty chain: A research agenda. Journal of the Academy of Marketing Science. 28 (1): 168-74.

Parasuraman, A., Zeithaml, V. A \& Berry, L. L. 1985.A conceptual model of service quality and its implication for future research. Journal of Marketing. 49: 41-50.

Parasuraman, A., Zeithaml, V. A \& Berry, L. L. 1988. SERVQUAL: A multiple-item scale for measuring consumer perceptions of service quality. Journal of Retailing. 64 (1): 12-40.

Parasuraman, A., Zeithaml, V. A \& Berry, L. L. 1994. Reassessment of expectations as a comparison standard on measuring service quality: implications for further research. Journal of Marketing. 58 (1): 111-24.

Park, C. 2004. Efficient or enjoyable? Consumer values of eating-out and fast food restaurant consumption in Korea. International Journal of Hospitality Management. 31 (1): 87-94

Permana, M. V. 2013. Improving Improved Customer Satisfaction Through Quality Products And Quality Service. Jurnal Dinamika Manajemen. 4 (2).

Rahim, M., Osman, M \& Ramayah, T. 2010. Service quality, customer satisfaction and loyalty: A 
Azman Ismail, dkk / Exploring Service Quality Impacts On Customer Satisfaction In Military ...

test of mediation. International Business Research. 3 (4): 72-80.

Rosen, D. E \& Suprenant, C. 1998. Evaluating relationships: Are satisfaction and quality enough? International Journal of Service Industry Management. 9 (2): 103-125.

Sánchez-Fernández, R \& Iniesta-Bonillo, M. A. 2007. The concept of perceived value: a systematic review of the research. Marketing Theory. 7: 427-451.

Saunders, S. G. 2008. Measuring and applying the PAKSERV service quality construct:Evidence from a South African cultural context. Managing Service Quality. 18 (5): 442-456.

Sekaran, U. 2010. Research Methods for Business: A skill Building Approach. New York: John Wiley \& Sons, Inc.

Ghobadian, A., Speller, S \& Jones, M. 1994. Service Quality. International Journal of Quality \& Reliability Management. 11 (9): 43-66

Sureshchandar, G. S., Rajendran, C \& Anantharaman, R. N. 2002. The relationship between service quality and customer satisfaction - a factor specific approach. Journal of Services Marketing. 16 (4): 363-379.

Tanisah \& Maftukhah, I. 2015. The Effects Of Service Quality, Customer Satisfaction, Trust, And Perceived Value Towards Customer Loyalty. Jurnal Dinamika Manajemen. 6 (1).
Tellis, G. J \& Gaeth, G. J. 1990. Best value, price seeking, and price aversion: The impact of information and learning on consumer choices. Journal of Marketing. 54: 34-45.

Tucker, J. L \& Adams, S. R. 2001. Incorporating patients' assessments of satisfaction and quality: an integrative model of patients' evaluations of their care. Managing Service Quality. 11: 272-87.

Vera, J. 2015. Perceived brand quality as a way to superior customer perceived value crossing by moderating effects. Journal of Product \& Brand Management. 24 (2): 147-156.

Woodruff, R. B. 1997. Customer Value: The next Source for Competitive Advantage. Journal of the Academy Marketing Science. 25 (2): 139154.

Woodruff, R. B \& Gardial, S. F. 1996. Know your customer. New approaches to understanding customer value and satisfaction. Cambridge: Blackwell Publishers, Inc.

Woodruff, R. B., Cadotte, E. R \& Jenkins, R. L. 1983. Modelling consumer satisfaction processes using experience-based norms. Journal of Marketing Research. 20: 296-304.

Zeithaml, V. A. 1988. Consumer perceptions of price, quality, and value: a means-end model and synthesis of evidence. Journal of Marketing. 52: 2-22. 